\begin{tabular}{l} 
RCCS \\
\hline Annual Review
\end{tabular}

\section{RCCS Annual Review}

A selection from the Portuguese journal Revista Crítica de Ciências Sociais

$2 \mid 2010$

Issue no. 2

\title{
The Military and Political Intervention: Ideological Trends and Contemporary Contexts
}

João Freire

Translator. Sheena Caldwell

\section{OpenEdition}

\section{Journals}

Electronic version

URL: https://journals.openedition.org/rccsar/227

DOI: $10.4000 /$ rccsar.227

ISSN: $1647-3175$

\section{Publisher}

Centro de Estudos Sociais da Universidade de Coimbra

Electronic reference

João Freire, "The Military and Political Intervention: Ideological Trends and Contemporary Contexts", RCCS Annual Review [Online], 2 | 2010, Online since 01 October 2010, connection on 21 September 2021. URL: http://journals.openedition.org/rccsar/227 ; DOI: https://doi.org/10.4000/rccsar.227 


\title{
João Freire
}

Instituto Superior de Ciências do Trabalho e da Empresa - Instituto Universitário de Lisboa (ISCTE-IUL), Portugal

\section{The Military and Political Intervention: Ideological Trends and Contemporary Contexts*}

\begin{abstract}
This article analyses the evolving relations between the military and political power in Portugal, from the time of the $19^{\text {th }}$ century liberal monarchy until the end of the $20^{\text {th }}$ century. In particular, it offers an interpretation of the impact of the diffusion of constitutionalist, republican, nationalist and socialist ideologies on military culture, and the norms guiding the attitudes and actions of military elites within the political arena. It takes into account their professional experience of war (the African campaigns, the First World War and the colonial war of 1961-74) and the observed behaviour of the working classes recruited for these missions, in the context of the policies adopted by successive governments and political regimes. The international context is also considered, both with regard to dominant ideologies and established strategic interests.
\end{abstract}

Keywords: The military; political power; military culture; armed interventions.

\section{Introduction}

Carrilho's work of 1985 amply demonstrated that the evolution of the social composition of the officer corps had a bearing on their relationship with the Portuguese context in specific eras (1910, 1926 and 1974). However, the same cannot be said of the prevailing political ideologies in each of these periods, despite the important contribution by Ferreira (1992). This is, therefore, the aim of this text: to attempt to examine the main outlines of the way in which, at the dawn of the $20^{\text {th }}$ century, Republicanism affected the officer corps trained under the constitutional monarchy; how, a few years later, a new movement based on authoritarian and anti-liberal ideas was able to mobilise a large portion of the military cadres to bring about a "return to order"; and how, after the experience of a prolonged war in the overseas territories, which was low intensity but employed subversive methods, the next generation of professional soldiers used their arms to bring down the ruling regime and many of them were tempted by various forms of allegiance to revolutionary socialist projects. This exercise will obviously involve skimming over Matos's (2008) arguments about, and exhaustive examination of, the relations between military institutions and political power throughout history, in order to present a few personal reflections, some of which have already appeared in published works on the subject of "political influences on the army" in the modern and contemporary world. To a certain extent, this represents the exact opposite

\footnotetext{
* Article published in RCCS 86 (September 2009).
} 
of the phenomena analysed by Matos, whose concern is with the "influence of the army on politics." However, the background also includes general reference works on the relations between the army, civil society and the state (Huntington, 1957), the sociology of war (Bouthoul, 1970; Keegan, 1976) and the imperial designs of the great powers (Kennedy, 1987).

What follows is an interpretative historical and political overview of the social attitudes of professional soldiers during the $20^{\text {th }}$ century, which should help formulate consistent hypotheses for the motives that led them, on occasion, to intervene directly (or attempt to do so) in the political arena through coups d'état, with the intention of altering the course of the government or the nature of the ruling regime. Although this overview refers concretely to the case of Portugal, it is not entirely specific to this country and its main lines of analysis correspond to general trends observable in other scenarios in the same periods, hence the inclusion of some comparative observations relating to situations in other countries (see, for instance, Girardet, 1964, for the case of France). It also refers, in general terms, to soldiers, but the intention is essentially to restrict this term to the body of professionals who choose a career in the armed forces and are the main repositories of military values and culture, historical memory and traditions. Additionally, they are the main reserve for the authority and intelligence that organise all operational units and that provide the rationale for the actions undertaken by the nation's armed forces. In other words, the main reference point here is the officer corps (those with fundamental responsibilities for commanding troops and the corresponding prerogatives), rather than the sergeants and ordinary soldiers, despite the fact that these subordinate ranks exist in much larger numbers. The text refers primarily to the army, as the larger and more influential branch of the armed forces, leaving slightly to one side aspects which are different and specific to the navy - the subject of a study by Freire (2003) - and the air force (still awaiting in-depth studies from a social sciences and humanities perspective, in Portugal at least), in order to focus on what they essentially share with their comrades in the ground forces: the military spirit.

In effect, the current idea of the armed forces as an integrated structure with three branches that essentially ensures national defence is relatively recent in origin, dating from the Second World War and the beginning of U.S. dominance. Before this, they were referred to as "land and sea" forces, supervised for a long time, at the level of government structure, by the War and Navy Ministries, respectively. It should, however, be noted that even in a 
country with an overseas empire such as the one that Portugal possessed in the first half of the $19^{\text {th }}$ century, the institutional framework for the defence of Portuguese sovereignty in such faraway places was never entirely satisfactorily resolved, bearing in mind the means of communication at the time. However, the location of the various theatres of operations and, without doubt, also the influences of the most powerful endogenous interests generally led to associating the army with the external actions of the state ("war" and diplomacy), whilst "navy and overseas affairs" were managed jointly (Barata \& Teixeira, 2003; Telo, 1999).

\section{Nineteenth-century constitutionalism and the end of the monarchy}

The experience of the civil war fought between the supporters of D. Pedro and D. Miguel - in the turbulent times following the French invasions, the withdrawal of the court to Brazil, the presence of the English and the first episodes in the Liberal revolution - must have been traumatic for many and, to a great extent, determined the profound reorganisation of the state which took place in the 1830s. From that time until almost the end of the $19^{\text {th }}$ century, continental Portugal was no longer under threat and the armed forces were only used occasionally to repress domestic reactions to unpopular measures which were part of the plans to modernize the country (the Patuleia, or "little civil war," and peasant uprisings) and to settle differences between opposing factions or figures from the dominant political elite (Cabralism, the Marechais, etc.). Essentially, these were cases of resistance on the part of the socio-cultural survivors of the Old Regime, faced with the arrival of "progress" (ranging from the free press to the railways) and the emergence of a bourgeois civilization in which wealth no longer depended exclusively on birth and the church was no longer (almost entirely) indistinguishable from the state. It should be noted that, with an essentially urban concept of the police dispersed on the streets dealing with vagrancy, soldiers were still responsible to a large extent for maintaining law and order in the territory, a duty which they exercised elegantly clad in breeches, short jacket and shako with plumes.

In these circumstances, the armed forces were experiencing the difficult transition from the former principle of personal loyalty to the monarch - to which may be added the near monopoly of the court aristocracy over the senior command, as Monteiro (2007) has clearly shown, despite recourse to foreign commanders and soldiers, paid at the going rate - and the new requirement of loyalty and service to the nation (Valente, 1997; Marques, 1999). As the nation was an abstract concept (although materialised in the form of territory and 
heritage, the population and shared language, in addition to religion), there was a need to make use of a combination of institutions to represent it and to find and define, tant bien que mal, a place on which the dependence and subordination of the military corps to decisions could be anchored: the ministry, the constitution, the king, parliament or the courts of law.

In addition, during this period the main organisational and functional pillars of the modern military institution were reformed and consolidated, involving:

- Training for the officer corps in specialist schools and the organisation of their professional careers on a functional and meritocratic basis;

- The codification of the principles of discipline, pay and the rights and duties of military status (for example, ending corporal punishment but, on the other hand, enshrining the swearing of allegiance to the flag and the obligation to serve the country "even at the sacrifice of one's own life");

- The organisation of compulsory military service for all able-bodied men;

- The importation of new weapons and equipment for troops (weapons with spiral barrels and breech loading, steamships, etc.).

In general, in these decades the idea that the military as an institution was a basic component of nationality itself, serving its people and respecting their history, was forged more consistently. In other words, the ideological basis of military nationalism (which may also translate into the idea of patriotism and is distinct from other forms of nationalism) was founded. It may be noted, as an aside, that this veritable mythology corresponded to the values extolled by the political class representing Liberal constitutionalism, but owed little to real history since, strictly speaking, it was only after the late $17^{\text {th }}$ century that reference could be made to a national army (i.e. a single army subordinate to the head of state, although raised in the provinces by municipalities and the nobility). However, it helped to construct the prestige of an institution which, through some of its most distinguished members (engineers, astronomers, geographers, etc.), was also involved in the economic and social development of the country following the civil war.

After the Berlin Conference of 1885, and given the urgent need for effective occupation of the overseas territories dictated by the course of history, Portuguese soldiers were called upon to fight "on the frontiers," in particular in Africa, in a series of operations and campaigns that were generally very successful (despite numerous setbacks), and which came 
to profoundly affect the political attitudes of the army. Despatched to exotic and distant lands, with precarious and difficult logistical bases and lines of communication, the army and navy officers (often marching across land or supporting these manoeuvres with rudimentary naval resources) were able to hone their skills (in commanding men) and qualities (decisionmaking, resourcefulness and daring) to take maximum advantage of the "human capital" entrusted to them, particularly the unselfishness, humility, obedience and spirit of sacrifice of the ordinary fighting man (Freire, 2009 and 2010).

At the same time, the most outstanding members of this elite quickly discovered unsuspected vocations as public administrators (in the new colonial administration installed in the territory after conquering the tribes and indigenous peoples) and various others were moved by scientific curiosity to explore and acquire detailed knowledge of the territories, their resources and populations. The official reports from the military campaigns and colonial government of the time were full of curious information about local history and culture, as well as references to prospects for the economic development of "future Brazils." At the same time, they took note of the incipient urban life in the small towns and cities where whites, natives and foreigners laboured, the random allegiances or submission of the indigenous authorities to the Portuguese flag (with the payment of the respective tax on huts), the violent incidents and acts that took place here and there, and the establishment of "outposts" (initially military and later administrative) to control vast territories, which were gradually linked by telegraph lines and roads opened after requisitioning "labourers" (albeit paid), managed by the Portuguese. From these "few brilliant and consoling pages in the history of contemporary Portugal" (as Mouzinho de Albuquerque wrote ${ }^{1}$ ), these men took the material needed to reinforce the model of the military hero, entirely and exclusively dedicated to serving his country, who was content simply to know he had done his duty and to receive some form of symbolic recognition from the country, such as decorations, tributes to the dead or, best of all, a place amongst the great names of Portugal.

The hesitations of these men from the "school of Mouzinho" - the history of Paiva Couceiro, mordantly characterized by Valente (2006), is a case in point - in the face of the subtleties and traps of state politics meant that the dizzying developments that took place at the beginning of the $20^{\text {th }}$ century - such as the working-class socialist movement, the

\footnotetext{
${ }^{1}$ In a letter to His Royal Highness Prince Luís Filipe in 1901, reproduced in Nunes (2003).
} 
women's suffrage movement or the aesthetic revolution in music or painting - passed this generation by, since they were powerless to control them and incapable of understanding them. However, the African experience had a profound effect on the memory of the generations that followed and armed them with a visceral distrust of "the swine, politics" (to quote Bordallo).

Moreover, during this period the process of social sealing of the officer corps, with descendants following the same vocation and reinforced family connections, was consolidated, meaning that authentic military lineages were created. If the aristocratic elitism of the officer class gradually disappeared, the entry of the best sons of the middle class and petty bourgeoisie (and more rarely the working class) into this group compensated for this with the advantages offered by a more substantial technical training (Carrilho, 1985).

\section{The spread of Republicanism}

The rapid and even overwhelming way in which, within around twenty years, Republicanism spread in Portugal amongst a significant portion of the urban bourgeoisie and acquired enthusiastic supporters amongst the Lisbon intellectuals, many shopkeepers and artisans and even the "hoi polloi" in working-class neighbourhoods and in the barracks is perhaps still surprising. The best-known and most consistent historiography has long ago identified the causes, described how it took place and discussed the consequences (Marques, 1977; Wheeler, 1978; Ramos, 1994). An example of the latter was the fact that, as it began later, it occupied the ground where working-class socialism was already developing, thus blocking the development of a central European type of social democracy and facilitating the course of the revolutionary syndicalist alternative. But it may be considered that the success of the Republican ideology and political movement had a lot to do with the degree of "rottenness" of the monarchy as an institution - that is to say, its inability to respond to the cultural challenges of the age, an area in which, in addition to the political class, the substantial influence of the Catholic church, still closely linked to power, weighed heavily - and, on a deeper level, with the intensification of the demagogic populist wave that had already swept through the country in 1820 (Valente, 1974; Cabral, 1979).

What is certain is that the Republican idea also won over many soldiers after the insurrection of 1891 (which has been called the "sargentada" [sergeants' revolt]), and also seeped through to the officer ranks, with motive and method. The motive was again 
constructed around the idea of nationalism, now understood as the opposite of "family intrigues and negotiations" inherent to the monarchy, refusing to allow Portuguese interests to be undermined by those of the English and importing supposedly scientific grounds (positivism) to legitimise its ambitions to the extent of accepting a federalist view of the state, as Fernandes discusses in detail (2008). The method was that of Carbonari conspiracy, whose roots dated far back in time but continued to prove effective in bringing down a regime "which many served but few supported," as was the case in Portugal. The result, for the military as an institution, was as follows: 'Torre e Espada' military honours bestowed on the heroes of the African occupation and an increase in the number of aides-de-camp in the royal military household were not sufficient to keep the army loyal to the government, ${ }^{2}$ and the "Republican virus" in the barracks caused a dual internal breakdown, due to political (and soon party) divisions introduced into its midst and to the habit of summoning armed troops to enforce any cause or objective supposedly beneficial to the country.

The "fathers of the Republic" and many of its ideologues were intelligent, educated, altruistic and (as far as we know) honest men who quickly understood the risks that politicised troops posed to the stability and credibility of the new regime. Participation in the First World War (see Teixeira, 1996) - involving approximately 50,000 members of the expeditionary forces, but apparently with reservations on the part of certain cadres concerning combat in the European theatre - with the main political objectives of guaranteeing possession of the colonies and making Portugal a partner recognized by the great European powers (in particular England, France and Spain), also came to serve the purpose of reunifying the armed forces and giving them a new sense of mission. The sacrifices made by thousands of career and non-career officers, sergeants and ordinary soldiers had, in fact, the psychological effect of creating a sense of "unity" and "being misunderstood by others" that are acknowledged to exist in most ex-combatants. Although the Republic had profusely honoured the efforts and heroism of these soldiers, thus reinforcing their patriotism, this did not redeem its original sin of partisanship and intrigue. Moreover, the everyday use of firearms meant that certain conscripts felt more ready to use them for their own purposes once they returned from the snow-covered fields of Flanders or the dry African steppes. Thus, the level of violence in society increased and armed soldiers

\footnotetext{
${ }^{2}$ See, for example, its composition in the Lista Annual de Antiguidades dos Officiaes da Armada[...] referida a 31 de Dezembro de 1902. Lisbon, IN, 1903.
} 
continued to intervene in politics, in plots generally directed against the "dictatorship of the democratic majority" (the party led by Afonso Costa), which was in reality the legal government (appointed by parliament), or as a response to restoring the "constitutional normalcy of 1911."

After Sidonism, an anti-Liberal political grouping began to take shape, in which many soldiers, marked by the experience of war (and its economic consequences) and discontent with the "scum" leading the country, were involved. Corporative questions (such as the integration of non-career officers into the permanent corps or more arms for the National Republican Guard [GNR]) and the deterioration of political and social life - with unstable government, a budget deficit, disorder in the streets and financial scandals - together with the profound changes taking place all over Europe (the USSR, Germany in crisis, Italian fascism, the rule of the military dictatorship in Spain, etc.), led to the emergence of nationalist movements (the Nuno Álvares League, etc.) and later to pre-seditious military juntas and, finally, to the revolution that was to "put the country in order" and bring about peace. Once again, nationalist values and references were brought into focus, attaching all the blame to the "Bernardinos Machados," as the political pamphlet written by the young lieutenant Humberto Delgado and entitled Da Pulhice do Homo Sapiens [On the Despicableness of Homo Sapiens] so clearly illustrates. ${ }^{3}$

Whereas Republican nationalism established itself against the "collusion of court and clergy," New State (Estado Novo) nationalism was built on the rejection of both demagogic politics and social disorder.

\section{Salazar's civil peace}

One of the strongest arguments that led the majority of the soldiers to give their long-lasting support to the New State was the rejection of political interference in the barracks and the reconquering of a sense of cohesion and unity that could only reinforce the military spirit. ${ }^{4}$ In fact, in addition to the involvement of uniformed personnel in a wide variety of coups and conspiracies, it was the military leaders who, for one reason or another, were involved (and involved the troops) in the main acts of force directed against serving governments, some of

\footnotetext{
${ }^{3}$ Published in 1931, passionately supporting the dictatorship (on the same subject, see also the book by Frederico Delgado Rosa, 2008).

${ }^{4}$ As an example from amongst many existing memoirs, see the book by General A. Ilharco (1926).
} 
which represented the most bloody civil struggles of the $20^{\text {th }}$ century in Portugal. Firstly, there were the 1911 and 1912 incursions from Galicia and the monarchist uprisings in Porto and Lisbon in January 1919 led by Paiva Couceiro, the insurrection of 14 March 1915 organised by the "democrats" to bring down the "dictatorial" government of General Pimenta de Castro, the military movement of 5 December 1917 led by Major Sidónio Pais (shot one year later by a member of the Republican Party), the aborted conspiracy of General Sinel de Cordes of 18 April 1925 and the applauded "national revolution" instigated by General Gomes da Costa on 28 May 1926 - not forgetting the confused and bloody night of 19 October 1921. Following this, there were the ferocious Republican and popular uprisings of 3 and 7 February 1927, the "Castle uprising" of 28 July 1928, the "Republic of Madeira" in April 1931 and the military movement of 26 August 1932, all opposing the government of the dictatorship and well analysed by Farinha (1998). In these various cases, armed civilians almost always played a part (non-mercenary volunteers, it should be noted) fighting alongside the military units in revolt, which conveys the impression of how normal violence was during this period (to which the bombers and civilian militias added in their own way ${ }^{5}$ ). Far more serious, however, was the responsibility of these insurrectionary officers, since they were seriously violating their duties as the armed wing of the nation (to defend it against attacks from abroad) and illegitimately forcing their subordinates to support their beliefs.

In addition, since political participation was a Republican right that did not exclude soldiers, countless army and navy officers joined the ranks of the governments of the $1^{\text {st }}$ Republic, the parliament at S. Bento and the lists of party members, inevitably adding to the divisions and verbal clashes "among comrades." The support base of the New State contained a combination of very diverse elements and political sensibilities. The National Union party itself was seen by many as a nonpartisan demonstration of support for a regime and a government that wanted to do "everything for the nation." It should not be forgotten that parliamentary democracy was heavily contested in the 1920s and 30s, both by populist and nationalist movements (in Italy, Germany, Spain, France, Hungary, etc.) and by the opposing alternatives represented by Communism and the USSR. It was therefore not surprising that some of the soldiers who assumed political duties in the New State did so to oppose the sterile partisanship and parliamentarianism of the $1^{\text {st }}$ Republic, and that others

\footnotetext{
${ }^{5}$ See, for example, the PhD dissertation in History by Filipa Freitas (2007).
} 
accepted posts in the state administration because they believed they were working for national resurgence.

Thus, Salazar's programme to "return the soldiers to the barracks" and "pacify the country" included the following measures:

- A drastic reduction in the level of violence and lack of safety in society, using the necessary means;

- The establishment of a designated "enemy within," firstly in the figure of the revolutionary working-class movement (which was defeated in the uprising of 18 January 1934) and later the Communist party (which served this purpose up to the end);

- The "soft" purging of the less trustworthy military leaders, as Faria (2000) and Matos (1999) have clearly shown;

- Plans to modernize war equipment, through the Magalhães Corrêa naval programme, spares from the Second World War, the creation of an air force, and NATO equipment (Telo, 1996);

- The appointment of senior officers to top prestigious state positions (Presidents of the Republic, military ministries, order of protocol, etc.);

- The adoption of measures of (indirect) economic support and social privilege for the "military family," making it more cohesive and isolating it a little more from the national collective (whilst maintaining the structural segmentation of the military hierarchy);

- Developing the essential vocation of the armed forces by identifying successive external threats looming over the integrity and independence of the country; while some of these were real, others were inflated for political reasons, but they always gave the soldiers the sense of their indisputable necessity and usefulness (the Spanish Civil War, the Second World War, the Cold War, India and, finally, the war in Africa, which "was instigated against us from the outside" and could only harm development in the overseas territories).

When the generation that had played a part in the establishment of the Republic and the First World War disappeared, serious political dissent in the military in fact ended, and the rare incidences of dissent or mere court conspiracies became minor phenomena without relevance or impact on the morale of the troops. The next generation, who served under the 
New State, ignored politics, in the best and worst sense, but this had a positive and considerable effect on cohesion, the professionalization of the cadres and the general efficiency of the armed forces, although it made them a crucial support base for the regime of Salazar - who was himself decorated with the 'Torre e Espada' by the military high command in May $1932 .^{6}$

In this way - through the heritage of the $19^{\text {th }}$ century, the consolidation of the institution itself, the campaigns and expeditions in distant lands and the experiences of political intervention - the ethics and culture of the contemporary Portuguese military was forged. The former refers to what should be, the military courts being responsible for its definition within the internal or corporative order, while the legitimate political power emanating from society is responsible for establishing its mission. The latter refers to what actually is and, from this perspective, can be examined and analysed, in particular through academic research (Freire, 2009a).

\section{The last of the African campaigns and the 1974 Revolution}

The Portuguese government reacted promptly and efficiently to the outbreak of "subversive wars" in Angola, Guinea and Mozambique - and was actually supported in this by the democratic opposition. There, soldiers were severely tested, overcoming difficulties of various types and leaving in the field proof of their loyalty and honour, with ten thousand killed and many maimed out of the approximately one million who were called up (Cann, 1997). However, the regime was unable to survive these protracted conflicts. The persistence of the local nationalist fighters and the (relative) international isolation of Portugal were the main exhaustion factors, but the end of the wars, the consequent independence of the territories and, above all, the fall of the actual regime in Lisbon only became possible because a significant number of lower ranking officers were moved to conspire and carry out a successful coup d'état.

During those years, the professional cadres of the army, navy and air force experienced the privations of a war without rules, for which they had not been prepared, in addition to the regular dramas involved in this kind of extreme situation. Many read Jean Lartéguy, ${ }^{7}$

\footnotetext{
${ }^{6}$ He was the first civilian to receive this honour (Martelo, 1999).

${ }^{7}$ The novels The Mercenaries, The Centurions and The Praetorians, about the wars in Korea, Indochina and Algeria, were published to great success in France in 1960 (the first two titles) and 1961, and soon translated into Portuguese and published by Bertrand.
} 
questioned their role as the centurions of the West (or the regime) and perhaps became disorientated by the ambiguous responses to their doubts. They also came into close contact with a new generation of students who, as conscripts, were forced to fight (or desert ...), and commanded a succession of troops who were the sons of workers and peasants from "inner Portugal," for whom they were the main role models - as fighters and as men (Brito, 19992001). Whilst some committed (or allowed) atrocities and adopted other forms of fearaverting behaviour, they were all able to see and assess the behaviour of the colonialists and the authorities and the poverty of African life on the basis of their personal experience and intervention. New solidarities were forged between soldiers from different ranks and separate branches. Orders from Lisbon or any headquarters, visits by important officials or information extracted by force by the PIDE (International and State Defence Police) seemed strange and abstruse to them at times. In the meantime, in everyday life, it was common to share combat rations with a black youth, light a cigarette in the mouth of a dead soldier or make a pious gesture towards an already helpless prisoner. ${ }^{8}$ Eventually, the large-scale mobilisation of conscripted officers and the "miscegenation" of the troops led to a more extensive occupation of the territories, and most of the actual fighting was transferred to the special forces (some of whom had been recruited locally), given them also the odiousness of the task at a time when international opinion had already been won over to the cause of independence.

This was the experience of the men responsible for the Revolution of 25 April 1974 although there were differences with regard to the navy and the air force. Given their basic training, they were not unaware that in setting out on this path they were violating the fundamental principles of military discipline and their duty to obey the legal government of the nation. Yet they believed that they were responding to the deepest aspirations of the majority of the Portuguese people and perhaps, to a certain extent, redeeming the armed forces from their political intervention at the start of the New State and the strong support they had given it for decades. In fact, from the first hours of the uprising and throughout the entire process that followed until the national situation was normalised as a constitutional and politically free democratic regime, the main objectives of Democratisation,

\footnotetext{
${ }^{8}$ Novels and memoirs of the colonial war (António Lobo Antunes, Carlos Vale Ferraz, etc.) are perhaps the best testimonies of this human experience.
} 
Decolonisation and Development were never questioned by significant sectors of the population.

However, the soldiers of the Revolution did not emerge unscathed from opening this veritable Pandora's Box. Politics - now warlike and youthful, driven by an important, diverse and revolutionary far left (Oliveira, 1993) - quickly entered the barracks, bases and ships, not to "raise the consciousness of the masses," but to sow division, capture allies and isolate the adversaries of the moment, consequently paralysing the mechanisms of the chain of command and neutralising the operations of the units. In addition to the climate of freedom previously experienced in 1910, the usual demoralisation that comes at the end of a war that has not been won (although not lost either), was now felt in the ranks, increasing the prevailing level of indiscipline even more. The MFA (Armed Forces Movement) itself, which had momentarily conceived of itself as a Third World-style liberation movement (Oliveira, 1975) quickly became an arena for the confrontation of different political and military opinions (and actions, with loyalties that went beyond the established hierarchies). Factions said to be from the right (the "Spinolistas"), the centre-left (the "Melo-Antunistas"), the left (the "Gonçalvistas") and the far left (the "Otelistas") - not to mention the "Kaulzistas" and other firm defenders of the deposed regime, were all caught up in the situation. To prevent bloodshed and fratricide, the important factors, amongst others, were the realism imposed by the international context, the timely reaction of Mário Soares, the military intervention of "the nine," the intelligence of Álvaro Cunhal in reining in conflict and the moderating and mediating role played by some officers, not always visible to the public, aided by the shared status of "comrades in arms" of all who were in disagreement with each other (Rezola, 2006).

Following the coup of 25 November 1975, the political scenario changed decisively for the forces of the movement, from a dynamic offensive with the aim of "carrying the revolution forward" to a situation of resistance and defence of the "conquests achieved."

But what could have led career officers, born and trained under the New State, to display such a great propensity for partisan divisions and undisguised sympathy for socialist and "anti-imperialist" ideologies to the point that, when the political regime stabilised from 1976 onwards, many adopted a "revolutionary," distrustful and critical attitude towards the democratic parties (from the Socialist Party to the right) and allowed themselves to be instrumentalized by the Communist sector (in all its shades), displaying a certain degree of tolerance towards the far left and even, as happens with all fronts - see the proximity to the 
so-called Catholic progressives or the role played by Marshal Costa Gomes in the Peace Movement of the 1970s and 80s (Rodrigues, 2008) - with conservative figures who accepted the score?

In order to answer this question, it is necessary to briefly recall the way in which, throughout the $20^{\text {th }}$ century, the main political movements considered the role of the military in the changes they were engaged in bringing about.

\section{Soldiers and politicians}

Let us leave aside fascism and Nazism, which organized their assault on state power through counter-revolutionary mass movements. After Jaurès and the "sacred unions" of the First World War, social democrat trends accepted without further question the mission of the armed forces in external defence, only expressing a preference for compulsory military service and a reticence towards professional armies. ${ }^{9}$ The orthodox Communist parties, on the basis of the historic experience of the civil war in Russia and their terrible struggle against the Germans from 1941 to 1945, began to consider the armed forces as a fundamental instrument in political action, both at home and abroad, and thought that, like the state itself, it should be firmly controlled by the party. ${ }^{10}$ Thus, with their notorious tactical flexibility, they were just as capable of attracting men with an inflexible military spirit (since they needed their powers of command and their technical knowledge) as they were of persecuting and ordering the execution of those who dared to denounce their thirst for control, as happened countless times during the Spanish Civil War ${ }^{11}$ and the Stalinist internal purges. In Portugal during the PREC (Ongoing Revolutionary Process), support for the peopleMFA alliance or for "comrade Vasco"12 was the order of the day and was instrumental in translating this orientation.

In turn, the Chinese communists ${ }^{13}$ had a very different experience in their "Iong march" to conquer the state (Gluksmann, 1969). They introduced a dual combination of nationalist objectives (against neighbouring invaders and "imperialists," the distant exploiters of their

\footnotetext{
${ }^{9}$ See the classic work by Jean Jaurès (1910).

${ }^{10}$ For technical concepts of assault on power from a Bolshevik perspective, see the 1931 book by A. Neuberg (1970).

${ }^{11}$ From the vast bibliography on this subject (and the violence of this "interior" war which also had a "front" and a "rearguard"), see Freire (2008).

${ }^{12}$ Coronel Vasco Gonçalves was Prime Minister of Portugal from 18 July 1974 to 19 September 1975. [T.N.]
} 
resources) with socialist-Marxist-Leninist objectives for the state control of the economy and the dictatorship of the party of the proletariat, on the one hand, and forms of conventional warfare with guerrilla warfare, on the other hand. Their concept of a people's army did not essentially differ from the one invented by the Bolshevists in 1919 , and it may be summarised thus: the regular troops were deployed in defence and conquest, whilst the rural or urban guerrillas provided the offensive, even when disadvantaged by lack of resources, and always under the control of the political commissars. ${ }^{14}$

This was the model which, in general, was copied by the Latin American guerrillas ${ }^{15}$ and to a great extent in the anti-colonial struggles in Africa, of which Portugal and its former overseas provinces had such a bitter experience (Afonso e Gomes, 1998). It can also be understood how, in other situations, nationalist soldiers who felt they had received little recognition from their political leaders (corrupt monarchies, puppet governments, etc.) and who were revolted by the submission of their country to the interests of foreign powers, could have opted for a "national revolution" to take over the reins of power, impose strong political regimes and engage in external campaigns that were more in keeping with their vision of the forces at play. This was what happened successively in Turkey, ${ }^{16}$ Egypt, Iraq, Libya, etc. In countries recently freed from colonialism in Africa (from Algeria to several in sub-Saharan Africa), in particular those where guerrilla warfare had taken place, the army also played an important role, together with the single party.

This is a plausible interpretation for the phenomenon of the synchrony between the traditional attitudes of the soldiers and the habitual values of the socialist movements (which appear to have nothing in common - consider, for example, hierarchy versus egalitarianism or obedience versus creativity), from the moment when the latter abandoned their initial ideas of internationalism and also began to defend national objectives and principles (as was the case with the domestic and foreign policy of the Bolsheviks after 1930), in addition, naturally, to the comfort of seeing themselves recognized and close to the state power of these new or refounded nations.

\footnotetext{
${ }^{13}$ See Mao Tse-tung's On Guerilla Warfare (1937; Portuguese translation from 2004) and also N. V. Giap, People's War, People's Army, originally published in 1961.

${ }^{14}$ See the works of Trostky collected in Comment la révolution s'est armée (1967) and L'Armée Rouge (1969).

${ }^{15}$ See Ernesto 'Che' Guevara (1971). The Brazilian Carlos Marighela also wrote a Mini-Manual do Guerrilheiro Urbano in 1969, the year in which he was killed in action.

${ }^{16}$ In this case, bringing profound internal changes in terms of the secularisation and modernisation of society.
} 
During this process, which lasted for thirty or forty years of the $20^{\text {th }}$ century, developments and changes began to take place in the habitual interventions of armies in the governance of their countries, which had formerly always been against movements and frequently against "Communism and all other subversive ideas"; and had always acted to impose order and the authority of the state, the unity of the nation and traditional values (religious, social or economic). It will suffice to recall the cases of Spain, Brazil, Indonesia, Greece, Chile and Argentina. This was a development that some must have taken as an encouragement to advance the cause of socialism by means of "national democratic revolutions." Their political strategies came to include infiltration of the military and, when circumstances justified it, alliances with the "progressive sector" of the army to prevent it from being controlled by the establishment.

All this meant that, in the case of Portugal in the 1970s, many professional soldiers felt attracted to such left-wing perspectives. Their sense of organisation, authority, methodical work, hierarchical decision-making and obedience to leaders was reflected much more in the internal discipline of the PC (Communist Party) and its "democratic centralism" than in the congenital parliamentarianism of the PS (Socialist Party) or the bold maximalism of the far left. ${ }^{17}$ Indeed, soldiers who have been attracted to political intervention have been, in general, more likely to form alliances with Communist parties, whose interests they end up serving, rather than with any other sector of the political spectrum. Moreover, nationalism (generous in some cases and more instrumental in others) can provide an ideological platform where they can meet, in addition to the fact that both cling to a unitary and centralist concept of power in human communities ("Politics needs strong direction," the Leninists say; "Whoever gives the orders, we will carry them out," reply the soldiers).

On the other hand, anarchism never had any penchant or place for the military (except for dissenters or deserters), given its internationalist (anti-nationalist), pacifist (anti-war but not necessarily non-violent) and anti-militarist (considering military leaders to have an interest in and to be responsible for wars) beliefs, in addition to its individualist attitudes (which did not exclude the community, but made it very difficult for the discipline of the barracks to be accepted) (see Freire, 1988). Likewise, the military were never seduced by this ideology, and

\footnotetext{
${ }^{17}$ See the writings of Álvaro Cunhal. Whilst there is no particular emphasis on the role of the military in the fall of the dictatorship in Rumo à Vitória, in A Revolução Portuguesa: O Passado e o Futuro (1976) the actions of the MFA are analysed in some detail. On this subject, see also Maxwell (1995) and Schmitter (1999).
} 
only a few isolated cases of defection to pacifism have been recorded, such as Von Müller (the commander of the Emden), Tibbets (the pilot of the Enola Gay) or the French general De Bolardière (a critic of the Gaullist force de frappe). The "military question" was only belatedly pondered by a small minority of Spanish anarcho-syndicalists - and by the Portuguese Jaime Brasil - who suggested ways to make armed defence more compatible with the libertarian spirit (organisation of volunteer militias, greater involvement of the lower ranks in hierarchical discipline and power, etc.). The story of the "anarchist lieutenants," transmitted orally by the famous Pedro da Silveira, ${ }^{18}$ refers to a group of young Azoreans who came to Coimbra in 1909 or 1910 to begin foundation studies before joining the School of Warfare and, caught up in the Coimbra euphoria of the immediate post-monarchist period (of the Demagogic Phalanx type or similar groups), became anarchists, at least for a few years, as was the case of Aurélio Quintanilha, Jaime Brasil, Hasse Ferreira, Adriano Botelho and even, surprisingly enough, Ortins de Bettencourt. ${ }^{19}$ But this was more of a student hoax than a political reality worthy of consideration. In any case, in the Portuguese political process that began in 1974 this ideological current showed no desire to intervene in the course of events (see Freire, 2007 and 1985).

Let me offer a final comment on the soldiers of the April revolution. Their generosity and loyalty to a certain idea of the Portuguese people cannot be questioned. However, it is legitimate to examine their public behaviour and try to understand the deep-rooted reasons for it - whether pleasant or not. In this sense, it would seem that, in addition to the more obvious causes already identified and generally invoked (war fatigue, etc.), a deeper explanation for the developments that took place (from the 1960s onwards) may be found in the weakening of the normative value of military nationalism. As already noted, this had been laboriously constructed during the $19^{\text {th }}$ century, and was the basis of the heavy involvement of the troops with Republicanism and later with the Salazar regime.

This gradual denationalisation of the attitudinal references of the military developed further with the path pursued from 1974 up to the present day. Once again, it has something to do with the loss of confidence in the main state leaders (yesterday, the ageing charismatic leaders; today, the allegedly corrupt politicians) and a lot to do with the general

\footnotetext{
${ }^{18}$ Pedro Laureano Mendonça da Silveira (1922-2003). A non-academic scholar, writer and poet born in the Azores, he was for many years a senior official at the National Library in Lisbon.

${ }^{19}$ Who would become Navy Minister under Salazar from 1936 to 1944, and probably the strongest Salazar supporter of all (Freire, 2003).
} 
cosmopolitanism that has emerged everywhere (with music, cinema, novels, TV, tourism, international marriages, and now the Internet...). It is also linked to the changes observed by Janowitz (1971) and Moskos and Wood (1988), which supposedly tended to make them closer to efficient professionals, one step away from security specialists and two steps away from the old mercenaries.

The nation was grateful to the soldiers of the April revolution for having put an end to the New State regime, ${ }^{20}$ given that few others would have been able to do so, at least in the way that it was done (without great violence or flashing lights), as also happened in the period of transition. But this recognition should be extended to the citizens that they also were, rather than the soldiers who, once again, had overstepped their duties, albeit this time for a "good cause." The exceptional nature of this fortunate intervention should have recommended greater discretion to them and the quickest possible return to their traditional mission. Was it the political conditions of the time that made this difficult?

After the "normalisation" of 1976, it is perfectly understandable that, in the context of the Cold War in which Portugal always remained a member of the western alliance against the socialist bloc, those known as the "military left" began to be seen by those in charge of the armed forces as persona non grata in matters relating to defence secrets and operational and senior decision-making posts. Knowing the solidarities that prevailed in this area, they could only be considered potential agents of an enemy "fifth column"- despite the feeling of injustice that this may have created in some. Yet, this sanitary cordon also met with strong internal opposition, both in the corporativism of the "comrades in arms," and in the status claimed by/attributed to the soldiers of the April revolution.

It should be added, as a final note, that military nationalism, although weakened, is still present today, above all implicitly, thanks to the diffuse anti-Americanism within public opinion, combined internally with a proto-unionist activism as a reaction to the loss of status of the military in society and in the eyes of the state. Society has imposed substantial cultural changes, including women in the army, multiculturalism, equality, associations, etc. (Carrilho, 1998; Matos e Bacalhau, 2001; Carreiras, 2002), whilst the state appears not to have yet

\footnotetext{
${ }^{20}$ The beginning of the Preamble to the Constitution approved in 1976 and still in force today praises them thus: "On 25 April 1974, the Armed Forces Movement, setting the seal on the Portuguese people's long resistance and interpreting its deep-seated feelings, overthrew the fascist regime. The liberation of Portugal from dictatorship, oppression and colonialism represented a revolutionary change and a historic new beginning in Portuguese society."
} 
clearly defined the mission that should now be attributed to the armed forces, wavering between concepts of defence and security and the links between national (Portuguese) and regional/global spaces (Rodrigues, 2004; Nogueira, 2005; Nogueira e Borges, 2006).

25 April 1974 was certainly a historic moment for contemporary Portugal. But having so decisively opened the door to the future, did the "men who never slept" imagine the future that awaited the armed forces?

Translated by Sheena Caldwell

Revised by Teresa Tavares

\section{References}

Afonso, Aniceto; Gomes, Carlos Matos (1998), Guerra Colonial: Angola, Guiné, Moçambique. Lisbon: Ed. Notícias.

Barata, L. Themudo; Teixeira, N. Severiano (eds.) (2003), Nova História Militar de Portugal, Vols. 4 \& 5. Lisbon: Círculo de Leitores.

Bouthoul, Gaston (1970), Traité de polémologie - la sociologie des guerres. Paris: Payot.

Brito, J. M. Brandão de (1999-2001), Revolução e democracia, 2 vols. Lisbon: Círculo de Leitores.

Cabral, Manuel Villaverde (1979), Portugal na alvorada do século XX: Forças sociais, poder político e crescimento económico de 1890 a 1914. Lisbon: Regra do Jogo.

Cann, John P. (1997), Counterinsurgency in Africa: The Portuguese Way of War, 1961-1974. Westport, CT: Greenwood Press.

Carreiras, Helena (2002), Mulheres em armas: A participação militar feminina na Europa do Sul. Lisbon: Cosmos/IDN.

Carrilho, Maria (1985), Forças armadas e mudança política em Portugal no século XX. Lisbon: IN-CM.

Carrilho, Maria (1998), Portugal no contexto internacional: Opinião pública, defesa e segurança. Lisbon: Cosmos/IDN.

Faria, Telmo (2000), Debaixo de fogo! Salazar e as forças armadas (1935-41). Lisbon: Cosmos/IDN.

Farinha, Luís (1998), O Reviralho: Revoltas republicanas contra a ditadura e o Estado Novo, 19261940. Lisbon: Estampa.

Fernandes, António Teixeira (2008), Nacionalismo e federalismo em Portugal. Porto: Afrontamento.

Ferreira, José Medeiros (1992), O comportamento político dos militares: Forças armadas e regimes políticos em Portugal no século XX. Lisbon: Estampa.

Freire, João (1985), "1974-1984: Evocação ou Renovação da Ideia Anarquista?”, Revista Crítica de Ciências Sociais, 15/16/17 (May), 163-170.

Freire, João (1988), "Ideologia, ofício e práticas sociais: o anarquismo e o operariado em Portugal 1900-1940." PhD dissertation in Sociology, Tecnhical University of Lisbon/ISCTE.

Freire, João (2003), Homens em fundo azul marinho: Ensaio de observação sociológica sobre uma corporação nos meados do século XX: A armada portuguesa. Oeiras: Celta.

Freire, João (2007), Pessoa Comum no Seu Tempo. Porto: Afrontamento. 
Freire, João (2008), "Espanha: violência e veemência”, A Ideia, 65 (October), 25-65.

Freire, João (ed.) (2009), Moçambique há um século, visto pelos colonizadores: Campanhas militares, ocupação do território, conhecimento dos povos (1895-1910). Lisbon: Ed. Culturais da Marinha.

Freire, João (2009a), "Instituições militares, poder político e sociedade," Nação e Defesa, $4^{\text {th }}$ Series, 123 (Summer), 135-174.

Freire, João (ed.) (2010), Olhares europeus sobre Angola: Ocupação do território, operações militares, conhecimento dos povos, projectos de modernização (1883-1918). Lisbon: Ed. Culturais da Marinha (forthcoming).

Freitas, Filipa (2007), "Les Jeunesses Syndicalistes au Portugal," PhD dissertation, École des Hautes Études en Sciences Sociales, Paris.

Giap, Vo Nguyen (1962), People's War, People's Army. English translation of work originally published in 1961. New York: Praeger.

Girardet, Raoul (ed.) (1964), La crise militaire française, 1945-1962: Aspects sociologiques et idéologiques. Paris: FNSP/A. Colin.

Gluksmann, André (1969), Le discours de la guerre. Paris: I'Herne.

Guevara, Ernesto 'Che' (1971), Oeuvres I: Textes militaires. Paris: Maspero.

Huntington, Samuel P. (1957), The Soldier and the State: The Theory and Politics of Civil-Military Relations. Cambridge, Mass.: Harvard University Press.

Ilharco, Alberto (1926), Memórias: Alguns apontamenos sobre a influência da política no exército. Porto: Chardron.

Janowitz, Morris (1971), The Professional Soldier: A Social and Political Portrait. New York: Free Press [1960].

Jaurès, Jean (1910), L'Armée nouvelle. Paris: L'Humanité.

Keegan, John (1976), The Face of Battle: A Study of Agincourt, Waterloo, and the Somme. London: Jonathan Cape.

Kennedy, Paul (1987), The Rise and Fall of the Great Powers. Economic Change and Military Conflict, 1500-2000. New York: Random House.

Mao Tse-Tung (2004), Problemas Estratégicos da Guerra Subversiva. Lisbon: Sílabo.

Marques, A. H. de Oliveira (1977), História de Portugal, vol. 2. Lisbon: Palas.

Marques, Fernando Pereira (1999), Exército, mudança e modernização na primeira metade do século $X I X$. Lisbon: Cosmos/IDN.

Martelo, David (1999), A espada de dois gumes: As forças armadas do Estado Novo (1926-1974). Mem Martins: Europa-América.

Matos, Luís Salgado de (2008), Como evitar golpes militares. Lisbon: ICS.

Matos, Luís Salgado de (1999), “Um 'estado de ordens' contemporâneo: A organização política portuguesa." PhD dissertation, University of Lisbon.

Matos, Luís Salgado de; Bacalhau, Mário (2001), As forças armadas em tempo de mudança: Uma sondagem à opinião pública nas vésperas do século XXI. Lisbon: Cosmos/IDN.

Maxwell, Kenneth (1995), The Making of Portuguese Democracy. Cambridge: Cambridge UP.

Monteiro, Nuno Gonçalo (2007), Elites e poder: Entre o Antigo Regime e o liberalismo. Lisbon: ICS [5 ${ }^{\text {th }}$ rev. ed.]. 
Moskos, Charles; Wood, Frank R. (eds.) (1988), The Military: More Than Just a Job? Washington DC: Pergamon Press.

Neuberg, A. (Heinz Neumann) (1970), Armed Insurrection. London: New Left Books [ $\left.{ }^{1} 1931\right]$.

Nogueira, J. M. Freire (ed.) (2005), Pensar a segurança e defesa. Lisbon: Cosmos/IDN.

Nogueira, J. M. Freire; Borges, J. Vieira (eds.) (2006), O pensamento estratégico nacional. Lisbon: Cosmos/IDN.

Nunes, António Pires (2003), Mouzinho de Albuquerque. Lisbon: Prefácio.

Oliveira, César (1975), M.F.A. e revolução socialista. Lisbon: Diabril.

Oliveira, César (1993), Os anos decisivos: Portugal 1962-1985. Lisbon: Presença.

Ramos, Rui (1994), "A Segunda Fundação (1890-1926)," in José Mattoso (ed.), História de Portugal, vol. 6. Lisbon: Círculo de Leitores.

Rezola, Maria Inácia (2006), Os militares na revolução de Abril: O conselho da revolução e a transição para a democracia em Portugal (1974-1976). Lisbon: Campo da Comunicação.

Rodrigues, Alexandre Reis (2004), Defesa e Relações Internacionais. Lisbon: Ed. Notícias.

Rodrigues, Luís Nuno (2008), Marechal Costa Gomes: No centro da tempestade. Lisbon: Esfera dos Livros.

Rosa, Frederico Delgado (2008), Humberto Delgado: Biografia do General Sem Medo. Lisbon: Esfera dos Livros.

Rosas, Fernando (1996), "O Estado Novo (1926-1974)," in José Mattoso (ed.), História de Portugal, vol. 8. Lisbon: Círculo de Leitores.

Schmitter, Philippe (1999), Portugal: Do autoritarismo à democracia. Lisbon: ICS

Telo, António José (1996), Portugal e a NATO: O reencontro da tradição atlântica. Lisbon: Cosmos.

Telo, António José (ed.) (1999), História da marinha portuguesa: Homens, doutrinas e organização, 1824-1974, vol. 1. Lisbon: Academia de Marinha.

Teixeira, Nuno Severiano (ed.) (2007), Os militares e a democracia. Lisbon: Colibri/IHC-FCSH-UNL.

Trotsky, Leon (1967), Comment la révolution s'est armée. Paris: I'Herne.

Trotsky, Leon (1969), L’Armée Rouge. Paris: I'Herne.

Valente, Vasco Pulido (1974), o poder e o povo: A Revolução de 1910. Lisbon: D. Quixote.

Valente, Vasco Pulido (1997), Os militares e a política (1820-1856). Lisbon: ICS.

Valente, Vasco Pulido (2006), Um herói português: Henrique Paiva Couceiro (1861-1944). Lisbon: Alêtheia.

Vaz, Nuno Mira (2002), 'Civilinização' das forças armadas nas sociedades demoliberais. Lisbon: Cosmos/IDN.

Wheeler, Douglas L. (1978), Republican Portugal: A Political History, 1910-1926. Madison: University of Wisconsin Press. 